\title{
Management of Propagation Techniques of the Specie Croton lechleri Muell.Arg
}

\author{
Jorge Zamir Erazo Amaya ${ }^{1,2}$, Kaoru Yuyama ${ }^{1,3}$, Edvan Alves Chagas ${ }^{1,4,5}$, Ismael Montero Fernández ${ }^{5}$ \\ Roberto Tadashi Sakazaki ${ }^{1} \&$ João Luiz Lopes Monteiro Neto ${ }^{1}$ \\ ${ }^{1}$ Postgraduate Program in Agronomy, University Federal of Roraima, Campus Cauamé, Boa Vista, RR, Brazil \\ ${ }^{2}$ Facultad de Ciencias Agrarias, Universidad Nacional de Agricultura, Catacamas, Olancho, Honduras \\ ${ }^{3}$ National Institute of Amazonian Research, Manaus, Amazonas, Brazil \\ ${ }^{4}$ Brazilian Agricultural Research Corporation-Embrapa, Boa Vista, RR, Brazil \\ ${ }^{5}$ Postgraduate Program in Biodiversity and Biotecnology, Campus Cauamé, Boa Vista, RR, Brazil \\ Correspondence: Jorge Zamir Erazo Amaya. Postgraduate Program in Agronomy, University Federal of Roraima, \\ POSAGRO/UFRR, Campús Cauamé, BR 174, s/n, Km 12, District Monte Cristo, Boa Vista, RR, Brazil. Tel: \\ 55-504-9608-4252. E-mail: ejorgezamir@yahoo.com
}

Received: September 22, 2018

Accepted: March 25, 2019 Online Published: May 15, 2019

doi:10.5539/jas.v11n6p486

URL: https://doi.org/10.5539/jas.v11n6p486

\begin{abstract}
With the aim of increasing the production of Croton lechleri Mull.Arg plants due to its attributes as a medicinal plant, the effect of different types of stakes and substrates as root promoters under intermittent nebulization conditions was evaluated. The work was conducted through a randomized complete block scheme adapting a factorial of $4 \times 3$, being the factors types of stakes (apical with leaves, apical without leaves, medium and basal) and substrates (sand, sand + Aserrin (1:1) and Aserrin (100\%) at the rate of 10 stakes per repetition totaling 360 stakes throughout the experiment. The percentage of root (\%), dead stakes (\%), sprouted stakes (\%), dead stake diameter was evaluated. $(\mathrm{mm})$, shoot length $(\mathrm{cm})$ and root length $(\mathrm{cm})$ The Aserrin provided the highest number of dead stakes and the smallest number of shoots in the species, with apical stakes with leaves and the combination of sand + Aserrin as a substrate providing the highest percentage of roots formed, therefore these two factors influence the production of plants in the dragon blood species.
\end{abstract}

Keywords: Dragon Blood, Amazon, medicinal plant

\section{Introduction}

In the Amazon region, there are a large number of medicinal species, many of which are used in medicine, produce leaves, fruits, stems and quality sap to treat the greatest number of human diseases (Froldi et al., 2009). Some of the developed countries import these products, provided by these exotic species, being these used as a supplement in diets (Almeida et al., 2008; Salatino et al., 2007).

Dragon Blood (Croton lechleri Mull. Arg), popularly known as blood grade, blood of water, Sangue de Dragão, belongs to the family of Euphorbiaceae, measures approximately between $35-45 \mathrm{~m}$ in height, its leaves are simple, with two small glands to join the petiole with the limb, its fruits are globose green yellow with size of 3 $\mathrm{mm}$ in length and $4 \mathrm{~mm}$ in width, it is a monoecious tree the hermaphrodite flowers of yellow color, its seeds in the form of ovoid with $3 \mathrm{~mm}$ in length and $2 \mathrm{~mm}$ wide (Palomino \& Barra, 2003; Gumarães \& Secco, 2010).

The species is a pioneer of rapid growth, tolerates floods and waterlogging, shows medicinal importance due to its sap used to heal wounds, treatment for gastric diseases and infections (Rossi et al., 2013; Savietto et al., 2013). Presenting in its chemical composition the Taspina alkaloid with antibacterial, anti-hemorrhagic, antiviral and antioxidant properties treating gastric problems of the stomach and intestine (Scalon et al., 2008).

The vegetative propagation by cuttings is used in most of the medicinal, fruitful and ornamental species generating quality plants where the agronomic characteristics are very efficient in terms of survival in final field, however results vary according to the species, internal factors and external to the plant (Bastos, 2005; Vernier \& Cardoso, 2013). For dragon blood most of the seedlings are removed from the place where it normally occurs, its propagation is still very unknown, obtaining negative results in some investigations, to produce roots of the 
species, inadequate management in the production of sap, the increase of the agricultural frontier, the occurrence of small populations in Brazil, are some of the difficulties that predominate, therefore necessary studies are necessary to domesticate and diversify the species (Osakada \& Yuyama, 2009).

The use of organic substrates in the production of plants is another factor to take into consideration since these provide nutrients that the stake needs to form roots. According to Sadhu (2005), any nutrient available for the associated metabolic processes in cell differentiation and root system formation is considered essential for their formation. Edaphoclimatic factors and others need control and care so that the induction of roots happens in a satisfactory way (Andrade, 2014). Therefore, this research aims to determine the capacity of roots formation of dragon blood stakes evaluated in organic substrates under an intermittent nebulization system.

\section{Material and Methods}

\subsection{Local}

It was developed in the fruit growing sector of the Brazilian agricultural research company (Embrapa, RR), in the summer season, located on the BR 174 highway, km 8, CP 133, Industrial District, Boa Vista, RR, in conjunction with the Federal University of Roraima. The municipality of Boa Vista is located at a latitude of $02^{\circ} 49^{\prime} 12^{\prime \prime} \mathrm{N}$ and longitude $60^{\circ} 40^{\prime} 23^{\prime \prime} \mathrm{W}$, at an altitude of $85 \mathrm{~m}$ above sea level, its climate is Aw type according to the classification of Köppen, annual rainfall of $1,667 \mathrm{~mm}$, relative humidity of $70 \%$ and room temperature around $27.4^{\circ} \mathrm{C}$ respectively (Neto et al., 2016).

\subsection{Collect of Vegetative Material}

The vegetative material comes from a small plantation of seven years old, on the mainland, in a particular place, located at BR 174, $\mathrm{km} \mathrm{8,} \mathrm{municipality} \mathrm{of} \mathrm{Manaus,} \mathrm{AM.} \mathrm{The} \mathrm{collection} \mathrm{was} \mathrm{done} \mathrm{in} \mathrm{the} \mathrm{morning} \mathrm{using} \mathrm{a} \mathrm{pruning}$ scissors, the branches were removed with $20 \mathrm{~cm}$ in length being kept in water, conditioned in plastic boxes containing ice in its base with the purpose of avoiding dehydration, then transported for the Fruit growing sector of Embrapa Roraima. In the nursery the stakes were prepared according to the treatment at a ratio of $20 \mathrm{~cm}$ in length the stem diameter varied by the different sizes of the evaluated stakes.

\subsection{Experimental Design}

The experiment was conducted under an experimental delineation of randomized complete blocks in a factorial scheme $(4 \times 3)$, with the factors being types of cuttings (apical with leaves (E1), apical without leaves (E2), median (E3) and basal (E4) and three types of substrates (sand (S1), sand + Aserrin (S2) and Aserrin (S3) Each experimental plot was composed of 10 stakes with four repetitions, after which the stakes were placed and conducted in greenhouse with a cover plastic and an intermittent nebulization system, the irrigation was programmed for 4 times a day lasting 6 minutes this with the purpose of avoiding stress generated by the environmental conditions of the region.

\subsubsection{Preparation of Treatments}

The substrates used in the experiment were prepared with the purpose of improving the conditions for the production of roots, the sand was obtained from the river bank branco, cast to facilitate the filling of the banks, the Aserrin obtained from the mountainous area industrial of the city of Boa Vista, this was cast using a $5 \mathrm{~mm}$ mesh, mineralized for a period of 3 months, the combination sand + Aserrin (1:1) has the purpose of intermediate effects of both substrates. The analysis of the materials was carried out following the methodology of (Silva, 2009).

\subsubsection{Variables Evaluated and Statistical Analysis}

Root production (\%), dead stakes (\%), shoots with shoots (\%), dead stake diameter (mm), shoot length (cm) and root length $(\mathrm{cm})$ at 84 days after installation of the experiment. These data were subjected to analysis of variance by the test of $\mathrm{F}$, and the means compared by the Tukey test at $5 \%$ probability, being processed through the statistical program SISVAR (Ferreira, 2011).

\section{Results and Discussion}

The summary of the analysis of variance (Table 1) showed a significant effect on the stake x substrate interaction for the variables of the dead stake diameter (DEM) and shoot length (LB). For the percentage variables of dead stakes (\% EM), percentage of stakes with shoots (\% EB), percentage of roots (\% R) and length of roots (LR) there were only significant simple effects of the type of stake and substrate. 
Tablet 1. Summary of the analysis of variance of number of dead stakes (\% EM), diameter of dead stake (DEM), number of stakes com brotos (\% EB), compression of broto (CB), percentage of enraizamento (\% E) and root compression (CR) of mutant drags (Croton lechleri Mull.Arg) produced by the type of stakes and different substrates. Boa Vista, RR, 2016

\begin{tabular}{|c|c|c|c|c|c|c|c|}
\hline \multirow{2}{*}{ FV } & \multirow{2}{*}{ GL } & \multicolumn{6}{|c|}{ Medium Squares } \\
\hline & & $\% \mathrm{EM}$ & DEM & $\% \mathrm{~EB}$ & $\mathrm{CB}$ & $\% \mathrm{E}$ & $\mathrm{CR}$ \\
\hline Block & 3 & $61.1^{\mathrm{ns}}$ & $0.84^{\mathrm{ns}}$ & $61.1^{\mathrm{ns}}$ & $0.34^{\mathrm{ns}}$ & $61.1^{\mathrm{ns}}$ & $5.90^{\mathrm{ns}}$ \\
\hline Piles (E) & 3 & $250.0^{* *}$ & $236.63^{* *}$ & $250.0^{* *}$ & $18.8^{* *}$ & $250.0^{* *}$ & $161.7^{\text {** }}$ \\
\hline Substrates (S) & 2 & $1706.3^{* *}$ & $1.63^{\mathrm{ns}}$ & $1706.3^{* *}$ & $279.8^{* *}$ & $1706.6^{* *}$ & $947.1^{* *}$ \\
\hline $\mathrm{E} \times \mathrm{S}$ & 6 & $64.58^{\mathrm{ns}}$ & $11.5^{* *}$ & $64.6^{\mathrm{ns}}$ & $10.6^{*}$ & $64.6^{\mathrm{ns}}$ & $42.03^{\mathrm{ns}}$ \\
\hline Residue & 33 & 44.44 & 1.81 & 44.44 & 3.44 & 44.44 & 21.98 \\
\hline C.V $(\%)$ & & 12.12 & 14.77 & 14.81 & 19.34 & 14.81 & 20.43 \\
\hline
\end{tabular}

Note. Legend: ns, * and **: Not significant, significant at $5 \%$ and significant $1 \%$ probability, respectively, by the test F. FV: source of variation; GL: degrees of freedom. EM: percentage of dead cuttings; DEM: diameter of the dead stake; \%EB: percentage of cuttings with shoots; $\mathrm{CB}$ : sprout compliance; \%E: rooting percentage; $\mathrm{CR}$ : root compliance.

In the percentage variable of dead stakes, the highest results were for the Arena and Aserrin treatments with 55.63 and 65\% respectively (Table 2). Probably, the high mortality was provided due to the low and high humidity in the substrates, associating the high temperatures in Greenhouse, one of the observations was that in the first 35 days of evaluation the stakes showed many shoots until they reached their death one week later, where medium and basal stakes presented the highest percentages of 57.5 and $60.0 \%$ respectively.

Palomino and Barra (2003) mention that the species does not present positive results in the propagation by cuttings in the species. According to Da Silva et al. (2009) deficiencies in essential elements of substrates increase the percentage of mortality. Another characteristic can be attributed to the absence of leaves in medium and basal stakes, these have the ability to capture solar energy for the production of carbohydrates that stimulate root formation (Abanto et al., 2014). However, Days et al. (2015) attribute this phenomenon to the thermal stress caused by the same greenhouse conditions, with intermittent coverage and nebulization.

For the diameter of the dead stake the basal stakes were the ones with the highest average $17.87(\mathrm{~mm})$ in treatment S2 (Sand + Aserrin), followed by S1 (Sand) 16.12 (mm) and S3 (Aserrin $12.39 \mathrm{~mm}$ ).

The apical stakes with and without leaves in all the evaluated substrates (Table 2) presented the lowest averages. This variable is very important at the time of selecting, with the advantage that some contribute higher amounts of auxins and other nutrients that help the process of root formation and outbreaks of plant species. According to Santos et al. (2011) the anatomy of the stalk in larger diameter stakes can act negatively in root formation and root quality formed. However, Ferreira et al. (2010) mention that the smaller diameters present high mortality percentages in Manihot glaziovii Mull.Arg, differing statistically in the results of this investigation.

The substrate that presented the highest percentage of sprouts sprouted was (Sand + Aserrin) in apical stakes with and without leaves at the rate of 55.62 and $44.37 \%$, it is attributed to the capacity of balanced moisture retention provided conditions to mobilize and use efficiently their nutritional reserves, where apical stakes with leaves obtained $50 \%$ of outbreaks, this factor is attributed to their hormonal reserves (Table 2). According to Cunha et al. (2012) this phenomenon is influenced to the levels of hormones, however an imbalance between axins, gibberalins and cytosines do not favor the process of bud formation in apical stakes. Luz et al. (2007) show that the highest percentage of shoots is provided in the sand as an ideal substrate in the vegetative propagation of herbaceous cuttings. 
Table 2. Average values in percentage for number of dead cuttings (\% MS), dead cutting diameter (DEM), number of cuttings with shoots (\% EB), length of shoot (CB), number of cuttings with root E) and root length (CR) of dragon blood seedlings (Croton lechleri Mull.Arg) produced on different substrates. Boa Vista, RR, 2016

\begin{tabular}{|c|c|c|c|c|c|c|c|c|}
\hline & \multicolumn{4}{|c|}{$(\%) \mathrm{EM}$} & \multicolumn{4}{|c|}{$\mathrm{DEM}(\mathrm{mm})$} \\
\hline & $\mathrm{S} 1$ & $\mathrm{~S} 2$ & S3 & Average & S1 & $\mathrm{S} 2$ & S3 & Average \\
\hline E1 & 45.0 & 42.5 & 62.5 & $50.0 \mathrm{c}$ & $5.71 \mathrm{Ac}$ & $5.17 \mathrm{Ac}$ & $6.87 \mathrm{Ab}$ & $5.92 \mathrm{c}$ \\
\hline E2 & 55.0 & 42.5 & 60.0 & $52.5 \mathrm{bc}$ & $5.97 \mathrm{Ac}$ & $5.64 \mathrm{Ac}$ & $6.93 \mathrm{Ab}$ & $6.17 \mathrm{c}$ \\
\hline E3 & 60.0 & 47.5 & 65.0 & $57.5 \mathrm{ab}$ & $8.84 \mathrm{Ab}$ & $8.97 \mathrm{Ab}$ & $8.93 \mathrm{Ab}$ & $8.91 \mathrm{~b}$ \\
\hline E4 & 62.5 & 45.0 & 72.5 & $60.0 \mathrm{a}$ & $16.12 \mathrm{Aa}$ & $17.87 \mathrm{Aa}$ & $12.39 \mathrm{Ba}$ & $15.46 \mathrm{a}$ \\
\hline \multirow[t]{3}{*}{ Average } & $55.63 \mathrm{~B}$ & $44.4 \mathrm{C}$ & $65.0 \mathrm{~A}$ & & $9.16 \mathrm{~A}$ & $9.41 \mathrm{~A}$ & $8.78 \mathrm{~A}$ & \\
\hline & \multicolumn{4}{|c|}{$(\%) \mathrm{EB}$} & \multicolumn{4}{|c|}{$\mathrm{CB}(\mathrm{cm})$} \\
\hline & $\mathrm{S} 1$ & $\mathrm{~S} 2$ & S3 & Average & S1 & $\mathrm{S} 2$ & S3 & Average \\
\hline E1 & 55.0 & 57.5 & 37.5 & $50.0 \mathrm{a}$ & 9.77 ABab & $11.25 \mathrm{Ab}$ & $7.0 \mathrm{Ba}$ & $9.34 \mathrm{ab}$ \\
\hline $\mathrm{E} 2$ & 45.0 & 57.5 & 40.0 & $47.5 \mathrm{ab}$ & 9.55 Bab & $15.0 \mathrm{Aa}$ & $5.30 \mathrm{Ca}$ & $9.95 \mathrm{ab}$ \\
\hline E3 & 40.0 & 52.5 & 35.0 & $42.5 \mathrm{bc}$ & $6.85 \mathrm{Bb}$ & 13.0 Aab & $4.25 \mathrm{Ba}$ & $8.03 \mathrm{~b}$ \\
\hline E4 & 37.5 & 55.0 & 27.5 & $40.0 \mathrm{c}$ & $11.85 \mathrm{Ba}$ & $16.0 \mathrm{Aa}$ & $5.25 \mathrm{Ca}$ & $11.03 \mathrm{a}$ \\
\hline \multirow[t]{3}{*}{ Average } & $44.37 \mathrm{~B}$ & $55.62 \mathrm{~A}$ & $35.0 \mathrm{C}$ & & $9.51 \mathrm{~B}$ & $13.81 \mathrm{~A}$ & $5.45 \mathrm{C}$ & \\
\hline & \multicolumn{4}{|c|}{$(\%) \mathrm{E}$} & \multicolumn{4}{|c|}{$\mathrm{CR}(\mathrm{cm})$} \\
\hline & S1 & S2 & S3 & Average & S1 & S2 & S3 & Average \\
\hline E1 & 55.0 & 57.5 & 37.5 & $50.0 \mathrm{a}$ & 35.63 & 20.95 & 24.87 & $27.15 \mathrm{a}$ \\
\hline E2 & 45.0 & 57.5 & 40.0 & $47.5 \mathrm{ab}$ & 25.2 & 15.05 & 14.70 & $18.30 \mathrm{~b}$ \\
\hline E3 & 40.0 & 52.5 & 35.0 & $42.5 \mathrm{bc}$ & 33.43 & 21.17 & 17.12 & $23.90 \mathrm{a}$ \\
\hline E4 & 37.5 & 55.0 & 27.5 & $40.0 \mathrm{c}$ & 32.8 & 12.43 & 22.23 & $22.47 \mathrm{ab}$ \\
\hline Average & $44.4 \mathrm{~B}$ & $55.6 \mathrm{~A}$ & $35.0 \mathrm{C}$ & & $31.74 \mathrm{~A}$ & $17.4 \mathrm{~B}$ & $19.73 \mathrm{~B}$ & \\
\hline
\end{tabular}

Note. Means followed by the same letter, lowercase in the columns and upper case in the lines, do not differ by Tukey test at $5 \%$ probability.

E1 = Apical with leaves, E2 = Apical without leaves, E3 = Median, E4 = Basal; S1 = Sand, S2 = Sand + Sawing $(1: 1)$, S3 = Sawing.

It was verified that the basal stakes evaluated in the substrate Sand + Aserrin presented the best results in length of shoots at a rate of $16.0(\mathrm{~cm})$, followed by the apical ones without leaves $15.0(\mathrm{~cm})$ and medium stakes 13.0 (cm) respectively, stakes with greater Diameters accumulate more reserves and photoassimilates in the formation of outbreaks (Santos et al., 2016). The lowest values were obtained in Aserrin as a substrate, attributing humidity as the main factor, observing that some shoots dried in all the cuttings (Table 2). These results agree with Pereira and Yuyama (2002) being that the length of shoots is greater in basal stakes due to their nutritive reversals, carbohydrates as an energy source for the production of new tissues and diameter of the stakes (Marchese et al., 2010; Biondi et al., 2008). Aserrin negatively influenced the length of shoots, a fact that is attributed to high humidity, can also be attributed to the genetic variability of the parent plants or the time of stalk collection (Abanto et al., 2014).

For percentage of roots formed (Table 2), the best means were obtained for apical stakes with leaves, tested on substrates composed of Sand and Sand + Aserrin, with 55 and 57.5\% respectively. According to Junior et al. (2009) the presence of leaves provides quantities of photo assimilates used in root formation. Same as the substrate allows greater availability of oxygen to the base of the stake, favoring the process of root formation (Gomes et al., 2015). These results show that the species has an affinity between moisture equilibrium, porosity and substrate temperature and the presence of leaves, which determined the greatest amount of root formed, being a determining factor for the success of the vegetative propagation of the plant species (Dias et al., 2012; Pereira et al., 2015). Aserrin provided the lowest percentages of roots in all types of stakes evaluated at a rate of $40 \%$ respectively, presenting greater callus formation, a particular feature of the pure substrate (Ristow et al., 2012).

In length of roots apical stakes with leaves, medium and basal provided 35.65, 33.43 and 32.8 (cm) containing sand as a substrate, the presence of leaves and the diameter of the stake influenced physiologically providing 
translocation of solutes and photo assimilates becoming quality factors (Pacheco \& Franco, 2008). The apical stalks without leaves obtained the smallest length of $18.30(\mathrm{~cm})$ in all the substrates evaluated, this due to the process of cell division that has a greater influence on the formation of apical meristems in this type of stakes (Vignolo et al., 2014).

\section{Conclusions}

The apical stakes with leaves presented the highest percentages of roots in the species Croton lechleri, being possible their propagation by the method of stakes if one has these morphological characteristics.

The best substrate was the combination Sand + Aserrin (1:1), in the formation of roots of the species Croton lechleri.

\section{References}

Abanto, R. C., Chagas, E. A., Choy, J. S., Santos, V. A., Lozano, R. M. B., \& Ríos, G. S. (2014). Capacidad de enraizamiento de plantas matrizes promisorias de Myrciaria dubia (Kunth) Mc Vaugh em cámaras de subirrigación. Revista Ceres Viçosa, 61, 134-140. https://doi.org/10.1590/S0034-737X2014000100018

Almeida, E. J., Jesus, N., Scaloppi, E. M. T., Martins, A. B. G., \& Araújo, M. S. (2008). Propagação de três genótipos de abieiro (Pouteria caimito) por estaquia de ramos herbáceos. Revista Acta Amazônica, $38,1-4$. https://doi.org/10.1590/S0044-59672008000100001

Andrade, J. K. C. (2014). Propagação vegetativa com o uso de estacas herbáceas de camu-camu (Myrciaria dubia (Kunth) Mc Vaugh) em câmara de subirrigação (p. 63, Dissertação de Mestrado, Universidade Federal de Roraima, Boa Vista, Roraima).

Bastos, D. C. (2005). Estiolamento, incisão na base da estaca e uso de AIB no enraizamento de estacas herbáceas de caramboleira. Revista Brasileira de Fruticultura, 27, 281-284. https://doi.org/10.1590/S0100-2945200 5000200023

Biondi, D., Bredow, E. A., \& Leal, L. (2008). Influência do diâmetro de estacas no enraizamento de Tecoma stans (L.) Juss. ex Kunth. Revista Semina, Ciências Agrarias, 29, 277-282. https://doi.org/10.5433/1679$0359.2008 v 29 \mathrm{n} 2 \mathrm{p} 277$

Cunha, C. S. M., Maia, S. S. S., \& Coelho, M. F. B. (2012). Estaquia de Croton zehntneri Pax et Hoffim. com diferentes concentrações de ácido indol butírico. Revista Ciência Rural, 42, 621-626. https://doi.org/ 10.1590/S0103-84782012000400007

Cunha, A. L. B., Chaves, F. C. M., Batista, A. C., \& Hidalgo, A. F. (2015). Propagação vegetativa de estacas de Piper hispidium Sw em diferentes substratos. Revista Brasileira de Plantas Medicinais, 17, 685-692. https://doi.org/10.1590/1983-084X/14_113

Da Silva, E. A., Maruyama, W. I., De Oliveira, A. C., \& Bardiviesso, D. M. (2009). Efeito de diferentes substratos na produção de mudas de mangabeira (Hancornia speciosa). Revista Brasileira de Fruticultura, 31, 925-929. https://doi.org/10.1590/S0100-29452009000300043

Dias, P. C., Ataíde, G. M., Xavier, A., De Oliveira, L. S., \& Paiva, H. N. (2015). Propagação vegetativa de Schizolobium amazonicum por estaquia. Revista Cerne, 21, 379-386. https://doi.org/10.1590/010477602015 21031467

Dias, P. C., De Oliveira, L. S., Xavier, A., \& Wendling, I. (2012). Estaquia e mini estaquia de espécies florestais lenhosas do Brasil. Pesquisa Florestal Brasileira, 32, 453-462. https://doi.org/10.4336/2012.pfb.32.72.453

Ferreira, D. F. (2011). Sisvar: A Computer Statistical Analysis System. Revista Ciência e Agrotecnologia, 35, 1039-1042. https://doi.org/10.4336/2012.pfb.32.72.453

Froldi, G., Zagotto, G., Filippini, R., Montopoli, M., Dorigo, P., \& Caparrota, M. (2009). Activity of sap from Croton lechleri on rat vascular and gastric smooth muscles. Revista Science Direct (Phytomedicine), 16, 768-775. https://doi.org/10.1016/j.phymed.2009.02.003

Gomes, J. A .O., Teixeira, D. A., Marques, A. P. S., \& Bonfim, F. P. G. (2015). Diferentes substratos na propagação por estaquia de assa-peixe (Vernonia polyanthes Lees). Revista Brasileira de Plantas Medicinais, 17, 1177-1781. https://doi.org/10.1590/1983-084x/15_008

Guimarães, L. A. C., Secco, R. S. (2010). As espécies de Croton L. sect. Cyclostigma Griseb e Croton L. sect. Luntia (Raf.) G.L. Webster subsect. Matourenses G.L. Webster (Euphorbiaceae s.s) ocorrentes na Amazônia Brasileira. Revista Acta Amazônica, 40, 471-488. https://doi.org/10.1590/S0044-59672010000300006 
Júnior, W. G. O. C., De Melo, M. T. P., \& Martins, E. R. (2009). Comprimento da estaca no desenvolvimento de mudas de alecrim-pimenta. Revista Ciência Rural, 39, 2199-2202. https://doi.org/10.1590/S010384782009005000152

Leandro, R. C., \& Yuyama, K. (2008). Enraizamento de estacas de castanha de cutia com uso de ácido indolbutirico. Revista Acta Amazônica, 38, 421-430. https://doi.org/10.1590/S0044-59672008000400001

Marchese, J. A., Pissaia, E., Bocchese, V. C. C., Cambruzzi, E., Colussi, G., Hart, V., \& Magiero, E. C. (2010). Estacas de diferentes diâmetros na propagação de Lippia alba (Mill.) N.E.Br.-Verbenaceae. Revista Brasileira, Plantas Medicinais, Botucatu, 12, 506-509. https://doi.org/10.1590/S1516-05722010000400015

Neto, J. L. L. M., Lima, N. D., Carmo, I. L. G. Da S., Da Silva, E. S., Da Silva, A. P., \& Medeiros, R. D. (2016). Sucessão de culturas e doses de nitrogênio no rendimento da melancia em condições edafoclimaticas de Savana.RevistaAgro@mbiente, 10,309-316. https://doi.org/10.18227/1982-8470ragro.v10i4.3462

Osakada, A., \& Yuyama, K. (2009). Propagação Vegetativa de Sangue de Dragão (Croton lechleri Mull.Arg) na Amazônia Central. In Congresso Nacional de Botânica, 59, 2009. Anais... Manaus: INPA, Programa de pós graduação em Botânica.

Pacheco, J. P., \& Franco, E.T. H. (2008). Substratos e estacas com e sem folhas no enraizamento de Luehea divaricata Mart. Revista Ciência Rural, 38, 1900-1906. https://doi.org/10.1590/S0103-84782008000700015

Palomino, Y. J., \& Barra, C. M. (2003). Espécies forestales nativas con potencial para refosrestación en la província de Oxapampa y fichas técnicas de las espécies de mayor prioridad (pp. 66-71). Programa Selva Central, Oxapampa, Peru.

Pereira, M. O., Wendling, I., Nogueira, A. C., Filho, A. N. K., \& Navroski, M. C. (2015). Resgate vegetativo e propagação de cedro-australiano por estaquia. Pesquisa Agropecuária Brasileira, 50, $282-289$. https://doi.org/10.1590/S0100-204X2015000400003

Ristow, N. C., Antunes, L. E. C., \& Carpenedo, S. (2012). Substratos para o enraizamento de micro estacas de Mirtileiro cultivar georgiagem. Revista Brasileira de Fruticultura, 34, 262-268. https://doi.org/10.1590/ S0100-29452012000100035

Rossi, D., Guerrini, A., Paganetto, G., Bernacchia, G., Conforti, F., Statti, G., ... Sacchetti, G. (2013). Croton lechleri Mull. Arg. (Euphorbiaceae) stem bark essential oil as possible mutagen-protective food ingredient against heterocyclic amines from cooked food. Food Chemistry, 139, 439-447. https://doi.org/10.1016/j. foodchem.2013.01.076

Sadhu, M. K. (2005). Plant Propagation (p. 281). New Age International Limited Publishers. India.

Salatino, A., Faria, S. M. L., \& Negri, G. (2007). Traditional uses Chemistry and Pharmacology of Croton species Euphorbiaceae. Journal Brazilian Society, 18, 11-33. https://doi.org/10.1590/S0103-505320070001 00002

Santos, J. P., Davide, A. C., Teixeira, L. A. F., Melo, A. J. S., \& Melo, L. A. (2011). Enraizamento de estacas lenhosas de Espécies florestais. Revista Cerne Lavras, 17, 293-301. https://doi.org/10.1590/S010477602011000300002

Santos, R. C., De Sousa, I. M., De Albuquerque, C. C., \& Silva, K. M. B. (2016). Tipo de estaca e substrato na propagação vegetativa de Lippia gracilis Schauer. Arquivos do Instituto Biológico, 83, 1-4. https://doi.org/ 10.1590/1808-1657000012014

Scalon, S. P. Q., Kodama, F. M., Scalon Filho, H., \& Mussury, R. M. (2008). Crescimento Inicial de mudas de sangra-d'água (Croton urucurana Baill.) sob sombreamento e aplicação de giberalina. Revista Brasileira de Plantas Medicinais, 10, 61-66.

Savietto, J. P., Furlan, C. M., Motta, L. B., Salatino, M. L. F., Carvalho, J. E., Ruiz, A. L. T. G., ... Santos, D. Y. A. C. (2013). Antiproliferative activity of methanol extracts of four species for Croton on different human cells lines. Brazilian Journal of Pharmacognosy, 23, 662-667. https://doi.org/10.1590/S0102-695X201 3005000058

Silva, F. C. (2009). Manual de análises químicas de solos, planta e fertilizantes (p. 627). Embrapa Informação Tecnológica, Brasília, DF: Embrapa Solos.

Vernier, R. M., \& Cardoso, S. B. (2013). Influência do ácido indol-butírico no enraizamento de espécies frutíferas e ornamentais. Revista Eletrônica de Educação e Ciência, 2, 11-16. 
Vignolo, G. K., Picolotto, L., Gonçalves, M. A., Pereira, I. D. S., \& Antunes, L. E. C. (2014). Presença de folhas no enraizamento de estacas de Amoreira-preta. Ciência Rural, 44, 467-472. https://doi.org/10.1590/S010384782014000300013

\section{Appendix A}

Table A1. Chemical analysis of the sawdust used as substrate in the dragon blood cutting experiment (Croton lechleri Muell.Arg)

\begin{tabular}{|c|c|c|c|c|c|c|c|c|c|c|c|c|}
\hline \multirow{2}{*}{ Substrate } & \multicolumn{12}{|c|}{ Chemical Characteristics } \\
\hline & $\mathrm{C}$ & $\mathrm{N}$ & $\mathrm{K}^{+}$ & $\mathrm{Ca}^{2+}$ & $\mathrm{Mg}^{2+}$ & $\mathrm{Al}^{3+}$ & $\mathrm{P}$ & $\mathrm{Mn}$ & $\mathrm{Cu}$ & $\mathrm{Zn}$ & $\mathrm{Fe}$ & B \\
\hline & \multicolumn{2}{|c|}{---- $\mathrm{g} \mathrm{kg}^{-1}$---- } & \multicolumn{4}{|c|}{------------ cmolc dm ${ }^{-3}$----------- } & \multicolumn{6}{|c|}{ 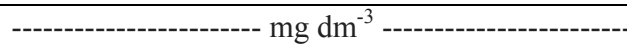 } \\
\hline Sawdust & 1.5 & 0.1 & 0.2 & 0.7 & 0.2 & 0.01 & 4.2 & 7.2 & 2.2 & 1.1 & 0.1 & 0.2 \\
\hline
\end{tabular}

Note. Analysis carried out in the laboratory of Chemistry and soil fertility of the Center of Agrarian Sciences, Cauamé Campus. Federal University of Roraima, Campus Cauamé (Brazil).

\section{Copyrights}

Copyright for this article is retained by the author(s), with first publication rights granted to the journal.

This is an open-access article distributed under the terms and conditions of the Creative Commons Attribution license (http://creativecommons.org/licenses/by/4.0/). 